\title{
PENINGKATAN PRODUKSI ASI IBU NIFAS SEKSIO SESAREA MELALUI PEMBERIAN PAKET “SUKSES ASI”
}

\author{
Tri Budiati ${ }^{1,2 *}$, Setyowati ${ }^{3}$, Novy Helena CD $^{3}$ \\ 1. Keperawatan Maternitas Fakultas Ilmu Keperawatan Universitas Indonesia, Depok 16424, Indonesia \\ 2. Program Studi Magister Fakultas Ilmu Keperawatan Universitas Indonesia, Depok 16424, Indonesia \\ 3. Fakultas Ilmu Keperawatan Universitas Indonesia, Depok 16424, Indonesia \\ *Email:umi_adhwa@yahoo.com,t-budiati@ui.ac.id
}

\begin{abstract}
Abstrak
Ibu nifas sering mengalami masalah menyusui diantaranya karena kurangnya produksi ASI. Penelitian ini bertujuan melihat keefektifan pemberian paket "SUKSES ASI" ibu menyusui dengan seksio sesarea terhadap produksi ASI di wilayah Depok. Penelitian ini menggunakan desain kuasi eksperimen dengan post test only design. Jumlah sampel adalah 29 orang kelompok intervensi dan 31 orang kelompok kontrol. Uji kesetaraan karakteristik didapatkan hasil tidak ada perbedaan bermakna antara kelompok intervensi dan kelompok kontrol ( $p>\alpha, \alpha \leq 0,05)$. Hasil uji analisis dengan Chi-Square didapatkan perbedaan yang bermakna antara kepuasan produksi ASI ( $\mathrm{p}=0,002$, OR 95\% CI 9,244), kelancaran produksi ASI dari indikator bayi $(\mathrm{p}=0,000, \mathrm{OR} 95$ $\%$ CI 9,000) dan kelancaran produksi ASI dari indikator ibu ( $\mathrm{p}=0,004$, OR $95 \%$ CI 0,181) antara kelompok intervensi dan kontrol. Diharapkan paket "SUKSES ASI" ini dapat digunakan dalam intervensi keperawatan maternitas, serta pengembangan paket yang lebih sempurna melalui penelitian lanjutan dengan survei pengkajian kebutuhan ibu post seksio sesarea untuk kelancaran produksi ASI.
\end{abstract}

Kata kunci: paket “SUKSES ASI", produksi ASI, seksio sesarea

\section{Abstract}

Postpartum mothers often have feeding problems include lack of milk production. This study purposed to look at the effectiveness of the package "SUKSES ASI" nursing mother with caesarean section on milk production in the area of Depok. This study used quasi-experimental design with a post test only design. Number of samples was 29 intervention group and 31 control group. Equivalence test characteristics obtained results no significant difference between the intervention and control groups $(p>\alpha, \alpha \leq 0,05)$. The results with the Chi-Square analysis found significant differences between milk production satisfaction $(p=0,002$, OR 95\% CI 9,244), the smooth production of the indicators of infant milk $(p=0,000$, OR 95\% CI 9,000) and lactation of indicators mothers $(p=0,004$, OR $95 \%$ CI 0,181) between the intervention and control groups. Expected package "SUKSES ASI" can be used in maternity nursing interventions, as well as the development of a more complete package through continued research with the needs assessment survey of post-caesarean section for maternal lactation.

Keywords: "SUKSES ASI" package, breast milk production, caesarean section

\section{Pendahuluan}

Penyebab kematian bayi yang terbanyak adalah diare dan masalah pemberian minum $(31,4 \%)$ dan pneumonia $(23,8 \%)$ (Riskesdas, 2007). Tingginya masalah kematian bayi ini dapat ditanggulangi jika bayi mendapatkan asupan yang baik serta gizi yang mencukupi, yaitu melalui pemberian ASI.

Data UNICEF (2007) menyebutkan pemberian ASI eksklusif selama enambulan pertama kelahiran dapat mencegah kematian sekitar 1,3 juta bayi di seluruh dunia tiap tahun. Namun menurut Survei Demografi Kesehatan Indonesia (SDKI) 2002-2003, hanya
39,5\% bayi yang diberi ASI eksklusif. Angka tersebut masih sangat jauh dari target Repelita VI yaitu sebesar $80 \%$, sedangkan pemberian susu formula terus meningkat hingga tiga kali lipat dalamkurun waktu lima tahun terakhir (Riskesdas, 2007).

Pengetahuan dan pemahaman menyusui yang benar sangat penting bagi ibu menyusui, baik kelebihan dan keuntungan pemberian ASI, teknik menyusui, dan kendala selama menyusui. Pada kenyataannya menyusui bukanlah suatu aktivitas yang terjadi secara otomatis, terutama pada ibu nifas seksio sesarea. Kondisi ini membutuhkan hal yang dapat memotivasi dan merubah cara pandang ibu mengenai menyusui. 
Hal ini sesuai dengan penelitian Lin, Chien-Hui, dan $\mathrm{Su}$-Chen (2008), yang menyatakan bahwa pengetahuan serta keterampilan menyusui ibu mempengaruhi kepercayaan diri ibu.

Persalinan dengan SC terus meningkat. Di Amerika persalinan dengan SC meningkat yaitu sekitar 1 dari 5 kelahiran pada tahun 1980, kemudian terjadi penurunan pada tahun 1990, dan kini menjadi meningkat kembali yaitu 1 dari 3 kelahiran (Rasjidi, 2009). Sementara di Indonesia di dapatkan data bahwa di Rumah Sakit Cipto Mangunkusumo Jakarta, kejadian SC terus meningkat pada tahun 2008 terdapat 40,04\% kasus SC meningkat 2,05\% dari tahun sebelumnya (Rekam Medik RSUPN CM, 2008). Peningkatan kejadian seksio sesarea ini juga secara tidak langsung menurunkan kesuksesan dalam menyusui. Hal ini pun didukung oleh penelitian yang dilakukan oleh Chertok dan Vardi (2008), yang menyatakan bahwa ibu-ibu yang melahirkan secara seksio berisiko tiga kali lebih besar untuk berhenti menyusui pada bulan pertama postpartum. Hal ini dikarenakan tidak dilakukannya inisiasi menyusu dini serta keterlambatan dalam memberikan ASI dibandingkan dengan ibu yang melahirkan secara normal. Selanjutnya, penelitian Indriyani (2006) menyatakan bahwa ada perbedaan yang signifikan antara produksi ASI ibu yang menyusui secara dini dan teratur pada ibu-ibu yang menjalani seksio sesarea di RSUD Dr Soebandi Jember dan Dr H. Koesnadi Bondowoso.

Perawat maternitas memiliki peranan penting dalam upaya meningkatkan kesuksesan menyusui pada ibu dengan seksio sesarea. Sebagai edukator, perawat maternitas dapat memberikan pendidikan kesehatan kepada ibu dengan seksio sesarea mengenai bagaimana cara meningkatkan produksi ASI serta upaya lain yang dapat meningkatkan produksiASI ibu pasca-operasi. Hal ini sejalan dengan penelitian yang dilakukan oleh Dhandapany dan Bethou (2008) bahwa pendidikan kesehatan yang diberikan pada masa antenatal dan postnatal pada 108 responden dapat meningkatkan kesuksesan menyusui.

Penelitian dengan metode intervensi yang dilakukan Dharmawati, Rustina, dan Sabri (2008), menunjukkan bahwa peningkatan pengeluaran ASI secara dini melalui kombinasi aerola massage dengan rolling massage pada ibu-ibu di puskesmas Pamulang dan Cikupa Banten. Namun, studitersebut belum melihat efektifitas intervensi terhadap kelancaran produksi ASI.

Penelitian perlu dilakukan untuk membuktikan efektivitas paket "SUKSES ASI" yang berisi perpaduan antara pemberian edukasi tentang menyusui dengan segala manfaat serta kelebihannya, langkahlangkah sukses menyusui dan perlekatan yang baik, dan bentuk intervensi yang dapat merangsang pengeluaran hormon oksitosin melalui pijat oksitosin. Selanjutnya peneliti mengangkat permasalahan penelitian yaitu: Bagaimanakah efektifitas pemberian paket "SUKSES ASI" terhadap kepuasan dan kelancaran produksi ASI ibu menyusui dengan seksio sesarea di Depok Jawa Barat?

\section{Metode}

Dalam penelitian ini peneliti menggunakan desain kuasi eksperimen, dengan post test only design with control group, yaitu suatu pengukuran hanya dilakukan pada saat akhir penelitian. Pengukuran kepuasan serta produksi ASI ibu dilakukan setelah kelompok intervensi diberikan paket "SUKSES ASI". Populasi pada penelitian ini adalah seluruh ibu prenatal yang berencana untuk melahirkan secara seksio sesarea yang memeriksakan kehamilannya secara rutin di Poliklinik kebidanan sebuah RS di Depok sebagai kelompok intervensi dan poliklinik kebidanan sebuah RS di Cibinong sebagai kelompok kontrol. Sampel diambil dari populasi dengan teknik consecutive sampling, sebanyak 29 responden pada kelompok intervensi dan 31 responden pada kelompok kontrol.

Pada kelompok intervensi: Pada masa prenatal, yaitu saat usia kehamilan responden 38-40 minggu, peneliti melakukan pengkajian fisik pemeriksaan payudara serta memberikan pendidikan kesehatan dengan memberikan booklet mengenai ASI yang meliputi manfaat ASI, keunggulan ASI dibandingkan dengan susu formula, perlekatan yang baik, serta bagaimana mengatasi masalah dalam pemberian ASI termasuk didalamnya ialah hal yang mempengaruhi produksi ASI, serta bagaimana mempertahankan produksi ASI. 
Tabel 1. Karakteristik Responden Berdasarkan Umur pada Kelompok Intervensi dan Kontrol

\begin{tabular}{lcccc}
\hline Kelompok & Mean & SD & Minimal-Maksimal & 95 \% CI \\
\hline Intervensi & 28,45 & 5,877 & $18-42$ & $26,21-30,68$ \\
Kontrol & 27,10 & 6,978 & $18-44$ & $24,54-29,66$ \\
\hline
\end{tabular}

Untuk memperjelas pemberian pendidikan kesehatan ini peneliti menggunakan boneka peraga untuk mendemonstrasikan posisi menyusui serta perlekatan yang benar. Pendidikan kesehatan dilakukan di ruang nifas yaitu satu hari sebelum klien dilaksanakan operasi. Peneliti juga meminta kesediaan responden untuk dilakukan intervensi pada 24 jam postoperasi untuk dilakukan pemijatan oksitosin.

Pada kelompok intervensi yang telah diberikan pendidikan kesehatan pada masa prenatal dikunjungi lagi pada 24 jam postoperasi dimana pada masa ini klien sudah mampu mobilisasi seperti duduk dan mulai belajar berjalan, peneliti dan kolektor data juga mengingatkan kembali kepada klien tentang materi yang telah diberikan pada masa prenatal dan aplikasi dari proses menyusui yang benar. Peneliti juga melakukan pijat oksitosin, pada saat melakukan pijat oksitosin ini peneliti juga mengajarkan pada pihak keluarga/ pasangan klien.

Adapun prosedur pelaksanaan pijat oksitosin adalah sebagai berikut: Responden diminta duduk diatas tempat tidur kemudian menunduk dengan bantuan bantal/ miring ke salah satu sisi, bra dan baju dibuka, ditutup dengan handuk, selanjutnya peneliti mengolesi telapak tangan dengan minyak kelapa, peneliti melakukan pemijatan pada tulang belakang searah jarum jam dari bawah keatas kurang lebih selama 15 menit. Selanjutnya peneliti juga meminta pihak keluarga, terutama pasangan untuk melakukan redemonstrasi pijat oksitosin serta meneruskan intervensi ini selama 2 kali sehari setiap 15 menit.

Produksi ASI dinilai pada kedua kelompok, yaitu kelompok intervensi dan kelompok kontrol, Penilaian produksi ASI ini dilakukan selama 3 hari setelah intervensi yaitu pada hari ketiga sampai dengan hari kelima postoperasi. Penilaian ini untuk menilai bagaimanakah produksi ASI pada kedua kelompok, adapun indikator lancar serta tidak lancar ini dengan melihat faktor ibu dan faktor bayi, kemudian membandingkan antara keduanya.

Analisis menggunakan univariat dilakukan untuk melihat sebaran dari karakteristik ibu antara lain; umur,

Tabel 2. Karakteristik Responden Berdasarkan Pendidikan, Paritas, Pengalaman dan Pekerjaan pada Kelompok Intervensi dan Kontrol

\begin{tabular}{lcccccc}
\hline \multicolumn{1}{c}{ Variabel } & Intervensi & \% & Kontrol & \% & n & Total \\
\hline Pendidikan & & & & & & \\
SD & 3 & 10,3 & 3 & 9,7 & 6 & 10,1 \\
SMP & 10 & 34,5 & 16 & 51,6 & 26 & 43,3 \\
SMA & 12 & 41,4 & 11 & 35,5 & 23 & 38,3 \\
PT & 4 & 13,8 & 1 & 3,2 & 5 & 8,3 \\
Paritas & & & & & & \\
Primipara & 13 & 44,8 & 16 & 51,6 & 29 & 48,4 \\
Multipara & 15 & 51,7 & 11 & 35,5 & 26 & 43,3 \\
Grande multipara & 1 & 3,4 & 4 & 12,9 & 5 & 8,3 \\
Pengalaman & & & & & & \\
Menyenangkan & 10 & 35,5 & 12 & 38,7 & 22 & 36,7 \\
Tdk Menyenangkan & 5 & 17,2 & 3 & 9,7 & 8 & 13,3 \\
Belum berpengalaman & 14 & 48,3 & 16 & 51,6 & 30 & 50,0 \\
Pekerjaan & & & & & & \\
Bekerja & 13 & 44,8 & 8 & 25,8 & 21 & 35,0 \\
Tidak Bekerja & 16 & 55,2 & 23 & 74,2 & 39 & 65,0 \\
\hline
\end{tabular}


tingkat pendidikan, serta paritas. Analisis bivariat yang digunakan dengan uji homogenitas serta uji dependensi.

\section{Hasil}

\section{Karakteristik Responden}

Gambaran karakteristik responden didapatkan bahwa rata-rata umur ibu pada kelompok intervensi adalah 28,43 tahun. Umur termuda pada kelompok intervensi dan kontrol adalah 18 tahun dan umur tertua 42 tahun pada kelompok intervensi dan 44 tahun pada kelompok kontrol (lihat tabel 1).

Pada tingkat pendidikan diketahui bahwa kelompok intervensi mayoritas responden memiliki pendidikan SMA (41,4\%). Pada kelompok kontrol mayoritas responden berpendidikan SMP $(51,7 \%)$. Berdasarkan paritas, pada kelompok intervensi mayoritas responden adalah ibu-ibu dengan multipara $(51,7 \%)$ sedangkan pada kelompok kontrol mayoritas ibu adalah dengan primipara $(51,6 \%)$. Sedangkan dari aspek pengalaman ibu tentang menyusui sebelumnya diketahui baik pada kelompok kontrol maupun kelompok intervensi adalah ibu-ibu yang belum berpengalaman $(48,3 \%)$ pada kelompok intervensi dan $(51,6 \%)$ pada kelompok kontrol. Hal ini sejalan juga dengan pekerjaan ibu, dimana baik pada kelompok intervensi maupun kelompok kontrol mayoritas responden tidak bekerja $(55,2 \%)$ pada kelompok intervensi dan $(74,2 \%)$ pada kelompok kontrol (lihat tabel 2).

Tabel 3. Perbedaan Responden Berdasarkan Umur pada Kelompok Intervensi dan Kontrol

\begin{tabular}{lcccc}
\hline Kelompok & Mean & SD & $\begin{array}{c}\text { Minimal- } \\
\text { Maksimal }\end{array}$ & p \\
\hline Intervensi & 28,45 & 5,877 & $18-42$ & 0,422 \\
Kontrol & 27,10 & 6,978 & $18-44$ & \\
\hline
\end{tabular}

Hasil uji kesetaraan karakteristik umur responden menunjukkan bahwa tidak ada perbedaan bermakna antara kelompok intervensi dan kontrol $(\mathrm{p}=0,422$, $\alpha \leq 0,05$ ) (lihat tabel 3). Pada hasil uji kesetaraan karakteristik pendidikan, paritas, pengalaman, dan pekerjaan responden juga menunjukkan bahwa tidak ada perbedaan yang bermakna antara kelompok intervensi dan $\operatorname{kontrol}(p=0,367 ; p=0,264, p=0,688$; $p=0,203, \alpha \leq 0,05)$ (lihat tabel 4).

\section{Kepuasan Responden}

Tabel 5 menunjukkan bahwa sebagian besar ibu pada kelompok intervensi $(89,7 \%)$ puas dengan produksi. Hasil ini menunjukkan bahwa ada perbedaan yang bermakna kepuasan ibu pada keluarga intervensi dan kontrol terhadap produksi ASI ( $p=0,002, \alpha \leq 0,05)$.

Tabel 4. Perbedaan Responden Berdasarkan Pendidikan, Paritas, Pekerjaan pada Kelompok Intervensi dan Kontrol

\begin{tabular}{|c|c|c|c|c|c|}
\hline \multirow{2}{*}{ Variabel } & \multicolumn{4}{|c|}{ Kelompok } & \multirow[b]{2}{*}{$\mathbf{p}$} \\
\hline & Intervensi & $\%$ & Kontrol & $\%$ & \\
\hline \multicolumn{6}{|l|}{ Pendidikan } \\
\hline SD & 3 & 10,3 & 3 & 9,7 & \multirow{4}{*}{0,367} \\
\hline SMP & 10 & 34,5 & 16 & 51,6 & \\
\hline SMA & 12 & 41,4 & 11 & 35,5 & \\
\hline PT & 4 & 13,8 & 1 & 3,2 & \\
\hline \multicolumn{6}{|l|}{ Paritas } \\
\hline Primipara & 13 & 44,8 & 16 & 51,6 & \multirow{3}{*}{0,264} \\
\hline Multipara & 15 & 51,7 & 11 & 35,5 & \\
\hline Grande multipara & 1 & 3,4 & 4 & 12,9 & \\
\hline \multicolumn{6}{|l|}{ Pengalaman } \\
\hline Menyenangkan & 10 & 35,5 & 12 & 38,7 & \multirow{3}{*}{0,688} \\
\hline Tdk Menyenangkan & 5 & 17,2 & 3 & 9,7 & \\
\hline Belum berpengalaman & 14 & 48,3 & 16 & 51,6 & \\
\hline \multicolumn{6}{|l|}{ Pek erjaan } \\
\hline Bekerja & 13 & 44,8 & 8 & 25,8 & \multirow[t]{2}{*}{0,203} \\
\hline Tidak Bekerja & 16 & 55,2 & 23 & 74,2 & \\
\hline
\end{tabular}


Selain itu, ibu yang diberikan paket SUKSES ASI berpeluang 9,244 kali untuk puas terhadap produksi ASI $(\mathrm{OR}=9,244)$ (lihat tabel 5).

\section{Kelancaran Produksi ASI dari Indikator Bayi}

Indikator kelancaran ASI pada alat observasi meliputi frekuensi dan karakteristik BAK, frekuensi, warna dan karakteristik BAB, jumlah jam tidur, serta berat badan bayi. Produksi ASI dikatakan lancar jika minimal 4 dari 6 indikator yang diobservasi terdapat pada bayi $(\leq 4)$. Sedangkan jika kurang dari $4(<4)$ dikatakan tidak lancar.

Hasil analisis efektifitas dari pemberian paket sukses ASI terhadap kelancaran produksi ASI ibu dari indikator bayi, diperoleh bahwa ada sebanyak 21 orang $(72,4 \%)$ ibu yang telah diberikan intervensi paket sukses ASI, produksi ASI-nya lancar. Pada kelompok kontrol hanya sebanyak 7 orang $(22,6 \%)$ produksi ASInya lancar sedangkan 24 orang $(77,6 \%)$ lainnya tidak lancar.

Hasil uji statistik menunjukkan bahwa ada perbedaan yang bermakna kelancaran produksi ASI dari indikator bayi ( $\mathrm{p}<0,0001, \alpha \leq 0,05)$. Dari hasil analisis juga diperoleh nilai OR 9,00 yang berarti ibu yang diberikan paket SUKSES ASI berpeluang 9 kali untuk lancar produksi ASI-nya dari indikator bayi (lihat tabel 6).

\section{Kelancaran Produksi ASI dari Indikator Ibu}

Produksi ASI dikatakan lancar jika hasil observasi terhadap responden menunjukkan minimal 5 indikator dari 10 indikator yang ada. Indikator itu meliputi payudara tegang karena terisi ASI, ibu rileks, let down refleks baik, frekuensi menyusui $>8$ kali sehari, ibu menggunakan kedua payudara bergantian, posisi perlekatan benar, puting tidak lecet, ibu menyusui bayi tanpa jadwal, ibu terlihat memerah payudara karena payudara penuh, payudara kosong setelah bayi menyusu sampai kenyang dan tertidur, serta bayi nampak menghisap kuat dengan irama perlahan.

Hasil analisis efektifitas dari pemberian paket sukses ASI terhadap kelancaran produksi ASI ibu dari indikator ibu, diperoleh bahwa ada sebanyak 21 orang $(72,4 \%)$ ibu yang telah diberikan intervensi paket sukses ASI, produksi ASInya lancar. Sedangkan sisanya sebanyak 8 orang $(27,6 \%)$ produksi ASInya tidak lancar setelah diberikan intervensi tersebut. Pada kelompok kontrol hanya 10 orang $(32,3 \%)$ yang produksi ASI-nya lancar sedangkan sisanya 21 orang $(67,7 \%)$ tidak lancar. Hasil uji statistik menunjukkan ada perbedaan yang bermakna kelancaran produksi ASI dari indikator ibu $(p=0,004, \alpha \leq 0,05)$. Dari hasil analisis diperoleh pula nilai $\mathrm{OR}=0,181$, yang artinya ibu yang diberikan paket SUKSES ASI berisiko 0,181 kali untuk tidak lancar produksi ASI-nya dari indikator ibu (lihat tabel 7).

\section{Pembahasan}

Usia merupakan salah satu faktor yang dapat mempengaruhi produksi ASI, ibu-ibu yang usianya lebih muda atau kurang dari 35 tahun akan lebih banyak memproduksi ASI dibandingkan dengan ibuibu yang usianya lebih tua (Biancuzo, 2000). Pada penelitian ini beberapa ibu yang memiliki usia lebih dari 35 tahun serta diberikan paket " SUKSES ASI" produksi ASI-nya lancar, hal ini dikarenakan masih adanya faktor lain yang mempengaruhi yaitu pengalaman, ibu dilakukan inisiasi menyusu dini sehingga bayi lebih segera untuk mendapatkan ASI serta rawat gabung.

Tabel 5. Perbedaan Tingkat Kepuasan Ibu pada Kelompok Intervensi dan Kelompok Kontrol

\begin{tabular}{|c|c|c|c|c|c|c|c|c|}
\hline \multirow{3}{*}{ Kelompok } & \multicolumn{4}{|c|}{ Kepuasan } & \multirow{2}{*}{\multicolumn{2}{|c|}{ Total }} & \multirow{3}{*}{$\begin{array}{c}\text { OR } \\
95 \% \mathrm{CI}\end{array}$} & \multirow{3}{*}{$\mathbf{p}$} \\
\hline & \multicolumn{2}{|c|}{ Puas } & \multicolumn{2}{|c|}{ Tidak Puas } & & & & \\
\hline & $\mathbf{n}$ & $\%$ & n & $\%$ & $\mathbf{n}$ & $\%$ & & \\
\hline Intervensi & 26 & 89,7 & 3 & 10,3 & 29 & $100 \%$ & 9,244 & $0,002 *$ \\
\hline Kontrol & 15 & 48,4 & 16 & 51,6 & 31 & $100 \%$ & $2,31-37,01$ & \\
\hline Total & 41 & 68,3 & 19 & 31,7 & 66 & $100 \%$ & & \\
\hline
\end{tabular}

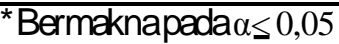


Beberapa penelitian di dalam dan luar negeri telah dilakukan untuk melihat keefektifan inisiasi menyusu dini (IMD) terhadap keberhasilan pemberian ASI secara eksklusif seperti penelitian yang dilakukan oleh Edmond, et al. (2006), tentang menunda IMD dapat meningkatkan kematian bayi. Penelitian Fika dan Syafiq (2003) dalam Roesli (2008), menunjukkan bayi yang diberi kesempatan untuk menyusu dini, hasilnya delapan kali lebih berhasil ASI eksklusif.

Begitu juga dengan penelitian yang dilakukan Rowe, Murray, dan Fisher (2002), bayi yang menyusu dini menunjukkan peningkatan dalam keberhasilan pemberian ASI eksklusif 2 - 3 bulan selanjutnya. Penatalaksanaan IMD tidak dapat berlangsung sukses jika ibu dan bayi tidak rawat gabung.

Salah satu kriteria dalam penelitian ini adalah ibu dan bayi harus rawat gabung, hal ini sejalan dengan penelitian Mathur, et al. (2003) menyatakan bahwa ada hubungan yang bermakna antara keberlangsungan menyusui dengan rawat gabung. Ibu-ibu dengan seksio sesarea yang dilakukan rawat gabung dapat meningkatkan kesuksesan menyusui sebesar 68,1\% jika dibandingkan dengan ibu-ibu yang dipisah.

Hal lain yang juga dapat mempengaruhi produksi ASI adalah paritas, meskipun dalam penelitian ini antara ibu yang primipara juga menunjukkan kelancaran produksi ASI. Penelitian yang mendukung hal ini adalah seperti penelitian Bonuck (2005) menyatakan bahwa ibu-ibu multipara menunjukkan produksi ASI yang lebih banyak dibandingkan dengan primipara pada hari keempat postpartum, tetapi setelah pola menyusui dapat dibangun dengan baik maka tidak terjadi perbedaan yang signifikan antara ibu primipara dengan multipara.
Pada penelitian ini para ibu yang bekerja sangat antusias sekali dengan materi pendidikan kesehatan dengan booklet tentang bagaimana cara memerah ASI dan menyimpannya serta cara memberikan ke bayi dengan menggunakan cangkir dan sendok. Besarnya motivasi ibu untuk belajar memerah dan menyimpan ASI sebelum ibu bekerja dapat meningkatkan kesuksesan dan keberlangsungan pemberian ASI pada ibu yang bekerja sejalan dengan penelitian yang dilakukan oleh Meek (2001) bahwa ibu-ibu yang diberikan dukungan, motivasi, serta panduan bagaimana memanajemen laktasi meningkatkan kesuksesan pemberian ASI ibu bekerja.

Ibu yang diberikan intervensi dengan paket intervensi "SUKSES ASI" melaporkan kepuasannya terhadap kelancaran produksi ASI-nya, serta puas karena produksi ASI-nya cukup untuk bayi mereka. Hasil ini sejalan dengan penelitian Bonuck, Freeman, dan Trombley (2006) terhadap ibu dengan seksio sesarea menyatakan bahwa produksi ASI yang lancar serta dukungan tenaga kesehatan mampu meningkatkan kepuasan ibu.

Begitu pula dengan penelitian yang dilakukan oleh Lin, Chien-Hui, dan Su-Chen (2008) bahwa kondisi psikologis ibu dengan seksio sesarea dan kelancaran ASI memiliki hubungan yang saling bermakna satu dengan yang lainnya. Semakin lancar produksi ASI semakin baik pula produksi ASI ibu, sebaliknya semakin baik kondisi psikologis ibu juga mampu mempengaruhi produksi ASI.

Penelitian ini juga menemukan bahwa adanya hubungan yang bermakna antara pemberian paket SUKSES ASI terhadap kelancaran produksi ASI dari indikator bayi.

Tabel 6. Perbedaan Kelancaran Produksi ASI Ibu dari Indikator Bayi Pada Kelompok Intervensi dan Kelompok Kontrol

\begin{tabular}{|c|c|c|c|c|c|c|c|c|}
\hline \multirow{3}{*}{ Kelompok } & \multicolumn{4}{|c|}{ Kelancaran } & \multirow{2}{*}{\multicolumn{2}{|c|}{ Total }} & \multirow{3}{*}{$\begin{array}{c}\text { OR } \\
95 \% \mathrm{CI}\end{array}$} & \multirow{3}{*}{$\mathbf{p}$} \\
\hline & \multicolumn{2}{|c|}{ Lancar } & \multicolumn{2}{|c|}{ Tidak Lancar } & & & & \\
\hline & $\mathbf{n}$ & $\%$ & $\mathbf{n}$ & $\%$ & $\mathbf{n}$ & $\%$ & & \\
\hline Intervensi & 21 & 72,4 & 8 & 27,6 & 29 & $100 \%$ & 9,000 & $0,0001 *$ \\
\hline Kontrol & 7 & 22,6 & 24 & 77,6 & 31 & $100 \%$ & $2,79-29,04$ & \\
\hline Total & 28 & 46,7 & 32 & 53,3 & 60 & $100 \%$ & & \\
\hline
\end{tabular}

*Bermakna pada $\alpha \leq 0,05$ 
Pada indikator bayi ini, aspek yang dinilai adalah frekuensi bayi buang air kecil (BAK), di mana bayi yang cukup produksi ASI-nya maka selama 24 jam paling sedikit bayi akan BAK sebanyak 6 kali, warna urin kuning jernih, jika ASI cukup setelah menyusu maka bayi tertidur/ tenang selama 2-3 jam (Bobak, Perry \& Lowdermilk, 2005; Perinasia, 2004; Cox, 2006). Pola eliminasi bayi tergantung dari asupan yang bayi dapatkan, bayi yang meminum ASI, umumnya pola Buang Air Besar/ BAB-nya dua sampai lima kali perhari, $\mathrm{BAB}$ yang dihasilkan adalah berwarna kuning keemasan, tidak terlalu encer dan tidak terlalu pekat (Pillitteri, 2003).

Penelitian ini membuktikan bahwa salah satu yang menyebabkan kerja hormon oksitosin baik adalah karena adanya rangsangan dari bayi serta ibu yang relaks, yang salah satu caranya adalah dengan perangsangan melalui pijat oksitosin Hal ini sejalan dengan penelitian yang dilakukan Suradi dan Roesli (2004) didukung pula oleh penelitian Dharmawati, Rustina, dan Sabri (2008) mengenai efektifitas kombinasi aerola massage dengan rolling massage terhadap pengeluaran ASI secara dini pada ibu- ibu di puskesmas Pamulang dan Cikupa Banten didapatkan hasil hubungan yang bermakna $(p=0,0016, \alpha \leq 0,05)$ bahwa ibu- ibu yang diberikan intervensi tersebut memiliki peluang 5,146 kali untuk terjadinya pengeluaran ASI kurang 12 jam setelah melahirkan.

Kerja hormon oksitosin ini juga dipengaruhi oleh isapan bayi, semakin sering bayi menyusu semakin sering hormon oksitosin terangsang. Untuk wanita pada umumnya, menyusui atau memerah ASI delapan kali dalam 24 jam menjaga produksi ASI tetap tinggi pada masa-masa awal menyusui, khususnya empat bulan pertama (Gartner, 2005). Penelitian Cregan, Mitoulas, dan Hartmann (2002) menemukan bahwa rata-rata bayi baru lahir menyusui adalah 10-12 kali menyusui tiap 24 jam, atau kadang lebih dari 18 kali. Hal ini merupakan cara terbaik untuk menjaga produksi ASI tetap tinggi dan bayi tetap kenyang.

\section{Kesimpulan}

Uji yang dilakukan terhadap kelompok intervensi dan kelompok kontrol menunjukkan hasil yang menyatakan bahwa responden pada kelompok intervensi dan kontrol keduanya homogen. Selain itu, penelitian ini juga menemukan tiga hal penting yaitu adanya hubungan yang bermakna antara pemberian paket "SUKSES ASI" terhadap kepuasan ibu ( $\mathrm{p}=0,002, \alpha \leq 0,05)$, kelancaran produksi ASI dari indikator bayi $(\mathrm{p}=$ $0,0001, \alpha \leq 0,05)$, dan kelancaran ASI dari indikator ibu $(p=0,004, \alpha \leq 0,05)$.

Dengan adanya penelitian ini, rumah sakit yang menjadi tempat penelitian dapat merasakan manfaatnya, diantaranya adalah ibu post seksio sesarea yang diberikan intervensi menjadi lebih mandiri dan memiliki keinginan kuat untuk menyusui bayinya secara dini. Beberapa masalah yang dihadapi ruangan seperti adanya berbagai keluhan seputar menyusui diawal masa nifas dapat berkurang. Hasil dari penelitian ini yaitu pemberian pendidikan kesehatan serta pijat oksitosin dapat diteruskan dilakukan di ruang nifas.

Paket "SUKSES ASI" ini dapat digunakan oleh rumah sakit sebagai bentuk intervensi yang membantu ibu dengan seksio sesarea dalam mengatasi masalah menyusui. Penelitian serupa perlu dilakukan dengan tempat penelitian yang berbeda serta sampel yang lebih besar.

Tabel 7. Perbedaan Kelancaran produksi ASI ibu dari Indikator Ibu pada Kelompok Intervensi dan Kelompok Kontrol

\begin{tabular}{|c|c|c|c|c|c|c|c|c|}
\hline \multirow{3}{*}{ Kelompok } & \multicolumn{4}{|c|}{ Kelancaran } & \multirow{2}{*}{\multicolumn{2}{|c|}{ Total }} & \multirow{3}{*}{$\begin{array}{c}\text { OR } \\
95 \% \mathrm{CI}\end{array}$} & \multirow{3}{*}{$\mathbf{p}$} \\
\hline & \multicolumn{2}{|c|}{ Lancar } & \multicolumn{2}{|c|}{ Tidak Lancar } & & & & \\
\hline & $\mathbf{n}$ & $\%$ & $\mathbf{n}$ & $\%$ & $\mathbf{n}$ & $\%$ & & \\
\hline Intervensi & 21 & 72,4 & 8 & 27,6 & 29 & $100 \%$ & 0,181 & $0,0004^{*}$ \\
\hline Kontrol & 10 & 32,3 & 21 & 67,7 & 31 & $100 \%$ & $0,06-0,55$ & \\
\hline Total & 31 & 51,7 & 29 & 48,3 & 60 & $100 \%$ & & \\
\hline
\end{tabular}

*Bermakna pada $\alpha \leq 0,05$ 
Penelitian lanjutan perlu dilakukan dengan menggunakan metode survei dengan pengkajian kebutuhan ibu nifas seksio sesarea terhadap kelancaran produksi ASI sehingga diperoleh paket yang lebih lengkap dan sesuai dengan apa yang dibutuhkan oleh ibu (MAW, YR, YA).

\section{Referensi}

Biancuzzo, M. (2000). Breastfeeding the newborn clinical strategies for nurses (1st Ed.). St. Louis, Missouri: Mosby Inc.

Bobak, I.M., Perry, S., \& Lowdermilk, D.L. (2005). Maternity nursing (4th Ed.). California: Mosby.

Bonuck, K.A., Freeman, K., \& Trombley, M. (2005). Randomized controlled trial of prenatal and postnatal lactation consultant intervention on duration and intensity of breastfeeding up to 12 months. Pediatrics, 116 (6), 1413-1426.

Chertok, I.R., \& Vardi, I.S. (2008). Infant hospitalization and breastfeeding post cesarean section. British Journal of Nursing, 17 (12), 786-791.

Cox, S. (2006). Breastfeeding with confidence: Panduan untuk belajar menyusui dengan percaya diri (Gracinia, J, Penerjemah). Jakarta: Gramedia. (sumber asli diterbitkan tahun 2001).

Cregan, M. Mitoulas, L., \& Hartmann, P. (2002). Milk prolactin, feed volume and duration between feeds in women breastfeeding their full-term infants over a 24 hour period. Exp Physiol, 87 (2), 207-214.

Dhandapany, G., \& Bethou, A. (2008). Antenatal counseling is it adequate? A descriptive study from pondicherry, India. International Breastfeeding Journal, 3 (5), 1-4.

Dharmawati, Rustina, Y., \& Sabri, L. (2008). Efektifitas kombinasi aerola massage dengan rolling massage terhadap pengeluaran ASI secara dini pada ibu nifas di Puskesmas Pamulang-Banten (Tesis, tidak dipublikasikan). FIK UI, Depok.

Edmond, K., et al. (2006). Delayed breast feeding initiation increases risk neonatal mortality. Journal Pediatrics, 117, 380-386.

Gartner, L.M., et al. (2005). Breastfeeding and the use of human milk. Pediatrics Journal,115(2),496-506.
Indriyani, D. (2006). Pengaruh menyusui dini dan teratur terhadap produksi ASI pada ibu postpartum dengan seksio sesarea di RSUD Dr. Soebandi Jember dan Dr. Koesnadi Bondowoso (Tesis, tidak dipublikasikan).Universitas Indonesia, Depok.

Lin, Chien-Hui, \& Su-Chen, K. (2008). Evaluating effects of prenatal breastfeeding education program on women with cesarean delivery in Taiwan. Journal of Clinical Nursing, 17 (21), 2838-2859.

Mathur, G.P., et al. (2003). Breastfeeding in babies delivered by cesarean section. Indian Pediatrics, 30 (11), 1285-1290.

Meek, J. Y. (2001). Breastfeeding in the workplace. Pediatrics Clinical North America, 48, 461-474.

Perinasia. (2004). Manajemen laktasi. Jakarta: Balai Pustaka.

Pillitteri, A. (2003). Maternal and childhealth nursing: Care of the childbearing and childrearing family (4th ed). Philadelphia: Lippincott.

Rasjidi, I. (2009). Manual seksio sesarea \& laparatomi kelainan adneksa: Berdasarkan evidence Based. Jakarta: Sagung seto.

Rekam Medik RSUPN CM. (2008). Data persalinan dengan SC terencana dan cito (Tidak dipublikasikan). Jakarta: RSUPN CM.

Riskesdas. (2007). Angka kesakitan dan kematian bayi di Indonesia. Diperoleh dari http:// old.depkominfo.go.id/portal/html.

Roesli, U. (2008). Inisiasi menyusui dini plus ASI eksklusif (Cet I). Jakarta: Pustaka Bunda.

Rowe, Murray, H. \& Fisher. (2002). Baby friendly hospital practices cesarean section is a persistent barrier to early initiation of breastfeeding. Birth, 29, 124-130.

Suradi, R., \& Roesli, U. (2008). Manfaat ASI dan menyusui. Jakarta: Balai Penerbit FK-UI.

UNICEF. (2007). Breastfeeding the remarkable first hour of life. Diperoleh dari www.unicef.go.id. 